\title{
SELF MANAGEMENT DIABETES PADA PASIEN DIABETES MELITUS DENGAN ULKUS DIABETIKUM DI PUSKESMAS JAGIR SURABAYA
}

\author{
Hendro Djoko Tjahjono* \\ STIKes William Booth Surabaya. Jl. Cimanuk No.20 Surabaya 60241. \\ hendrodjokotjahjono@yahoo.co.id
}

\begin{abstract}
ABSTRAK
Diabetes Melitus (DM) saat ini masih menjadi masalah serius di negara-negara berkembang. Prevalensi yang cenderung meningkat dan penanganan yang tidak baik berdampak pada kejadian komplikasi. Salahsatu komplikasi yang dialami pasien DM adalah Ulkus Diabetikum. Penelitian ini bertujuan untuk mengetahui self management diabetes (SMD) pada pasien DM. Desain penelitian yang digunakan analisis deskriptif dengan pendekatan cross-sectional. Variabel penelitian yaitu self management diabetes (SMD) pada pasien DM. Populasi dalam penelitian ini adalah seluruh pasien DM di Puskesmas Jagir Surabaya. Sampel yang diambil sebanyak 18 responden melalui consecutive sampling. Data penelitian dikumpulkan menggunakan kuesioner SMD. Hasil penelitian menunjukkan SMD pasien DM yaitu katagori cukup sebanyak 10 orang (56\%). Puskesmas dan tenaga kesehatan dapat menjadi sarana dan fasilitator bagi penderita DM dalam meningkatkan kemampuan SMD melalui edukasi, promosi kesehatan secara berkala dan kontinyu kepada pasien dan juga kepada keluarga sebagai support system pasien dalam dukungannya pada berbagai hal terkait penatalaksanaan DM.
\end{abstract}

Kata Kunci : Diabetes Melitus, Self Management Diabetes

\begin{abstract}
Diabetes Mellitus (DM) still currently became to serious problem in developing countries. The prevalence tends increasing and poor treatment has an impact on the incidence of complications. This study aims to determine diabetes selfmanagement (SMD) in DM patients. One of the DM patients complications is Diabetic Ulcer. The research design used descriptive analysis with a crosssectional approach. The research variable was diabetes self management (SMD) in DM patients. The population in this study were all DM patients at Puskesmas Jagir Surabaya. The samples taken were 18 respondents through consecutive sampling. The research data were collected using the SMD questionnaire. The results showed that the SMD of DM patients was a sufficient category that is 10 people $(56 \%)$. Puskesmas and health workers can meaning and as facilitator for DM sufferers to increasing the ability of SMD through regulary and continuous education, health promotion to the patients and also to their families as patient support systems to helping for various matters related to DM management treatments.
\end{abstract}

Keywords: Diabetes Mellitus, Self Management Diabetes. 


\section{PENDAHULUAN}

Penyakit merupakan suatu keadaan abnormal dari tubuh atau pikiran yang menyebabkan ketidaknyamanan, disfungsi atau kesukaraan terhadap orang yang terkena atau terserang penyakit tersebut. Dengan kata lain penyakit dapat dipahami sebagai sebuah keadaan tidak stabil dalam system koordinasi tubuh yang dapat berdampak pada tidak produktifitasnya manusia secara sosial dan ekonomi. Secara umum penyakit dapat di klasifikasi menjadi dua bagian utama. Pertama, penyakit menular (PM). Penyakit menular adalah penyakit yang di sebabkan oleh kuman, virus, bakteri yang menyerang tubuh manusia. Kedua, penyakit tidak menular (PTM). Penyakit tidak menular adalah penyakit yang di sebabkan karena adanya masalah fisiologi atau metabolisme pada jaringan tubuh manusia. Tuntutan gaya hidup di era globaliasasi yang semakin meningkat akibat adanya perubahan budaya dan sosial yang cepat, populasi penuaan yang semakin meningkat, perubahan pola makan, akitivitas fisik yang kurang dan perilaku atau gaya hidup yang tidak sehat menyebabkan manusia atau individu mudah terserang penyakit, seperti penyakit tidak menular (PTM), salah satunya Diabetes Melitus (DM) yang ditunjukkan dengan tingginya angka kejadian DM dan komplikasinya yang terus meningkat secara drastis setiap tahunnya. Penyakit ini masih menjadi prioritas dan masalah kesehatan utama yang perlu ditangani di negara - negara berkembang termasuk Indonesia.

DM merupakan penyakit kronik kompleks yang melibatkan kelainan metabolisme karbohidrat, protein, lemak dan dapat berkembangnya komplikasi makrovaskuler, mikrovaskuler dan neurologis (Barbara, 2002). Komplikasi yang sering terjadi pada penderita DM adalah adanya luka pada kaki. Ulkus diabetikum atau luka DM adalah kerusakan sebagian (partial thickness) atau keseluruhan (full thickness) pada kulit yang dapat meluas ke jaringan di bawah kulit, tendon, otot, tulang atau persendian yang terjadi pada seseorang yang menderita penyakit DM, kondisi ini timbul sebagai akibat terjadinya peningkatan kadar gula darah yang tinggi. Jika ulkus diabetikum berlangsung lama, dan tidak dilakukan penatalaksanaan dengan baik serta lukanya tidak sembuh - sembuh maka luka tersebut akan menjadi terinfeksi. Ulkus kaki yang sudah terinfeksi sering mengakibatkan munculnya gangren dan bisa juga berujung amputasi pada ekstremitas bawah.

Ulkus diabetikum merupakan salah satu komplikasi kronik DM yang ditakuti oleh semua orang. Hasil penelitian yang dilakukan oleh Sitorus (2011), mengatakan pada penderita DM dengan ulkus diabetikum memiliki konsep diri yang kurang terkontrol terutama pada body image yang negatif terhadap dirinya sendiri. Hal ini terjadi karena penerimaan diri pasien terhadap penyakitnya kurang baik atau bisa juga disebut koping individu inefektif. Secara tidak langsung, individu dengan penerimaan diri buruk akan berpandangan negatif terhadap kemampuannya dalam mengelola penyakitnya, sehingga dapat memengaruhi dalam proses self-management diabetes (SMD. SMD merupakan suatu perilaku yang berfokus pada peran serta tanggung jawab individu dalam pengelolaan penyakitnya yang meliputi tindakan individu dalam mengontrol diabetes termasuk melakukan pengobatan dan pencegahan komplikasi. (Kisokanth et al., 2013). WHO (2013) memperkirakan pada tahun 2030 jumlah pasien DM akan semakin meningkat hingga mencapai 438 juta orang dan menjadi penyebab kematian yang menempati urutan ke-7 di dunia. Data dari International Diabetes Federation (IDF) Atlas tahun 2017 menunjukkan bahwa Indonesia menduduki peringkat ke-6 dunia dengan jumlah diabetesi sebanyak 10,3 juta jiwa. Indonesia sendiri menduduki peringkat ke-4 pasien DM terbanyak di dunia dengan jumlah pasien mencapai angka 76 juta orang pada rentan usia sekitar 20-79 tahun. Angka ini diperkirakan akan terus meningkat mencapai 21.257.000 pasien DM di Indonesia pada tahun 2030. Selain itu DM menduduki peringkat ke-6 penyebab kematian terbesar di Indonesia (The Centers For Disease Control And Prevention). Riset Kesehatan Dasar 
(Riskesdas) 2018, secara umum menunjukkan peningkatan yang cukup signifikan prevalensi diabetes selama lima tahun terakhir. Di tahun 2013, angka prevalensi diabetes pada orang dewasa mencapai 6,9 persen, dan di tahun 2018 angka terus melonjak menjadi 8,5 persen. Prevalensi klien ulkus kaki diabetik di dunia sekitar $15 \%$ dengan risiko amputasi 30 $\%$, angka mortalitas 32\% (IDF, 2017). Penderita diabetes di Indonesia yang mengalami komplikasi ulkus diabetikum sekitar $15 \%$ angka amputasi $30 \%$ angka mortalitas $32 \%$ dan ulkus diabetikum merupakan penyebab perawatan rumah sakit yang terbanyak sebesar $80 \%$ untuk DM. Data Riset Kesehatan Daerah (Riskesdas) menunjukkan bahwa prevalensi penderita diabetes provinsi Jawa Timur masuk 10 besar se-Indonesia dengan prevalensi $6,8 \%$ (Kominfo, 2015). Data yang termuat dalam Profil Dinas Kesehatan Kota Surabaya tahun 2017 terdapat 17.319 jiwa yang menderita DM dari jumlah penduduk Kota Surabaya sebanyak 2.874.699 jiwa. Salah satu wilayah Kota Surabaya yang memiliki insiden DM mencapai 7246 jiwa adalah Kecamatan Wonokromo dari total jumlah penduduk sebanyak 93.581 jiwa. Di wilayah Kecamatan Wonokromo terdapat 6 Kelurahan dengan rata-rata setiap Kelurahan memiliki insiden kasus DM. Insiden DM tertinggi terdapat di Kelurahan Jagir dengan 976 kasus dari total penduduk sejumlah 10.4908 jiwa (Profil Puskesmas Jagir, 2017). Berdasarkan hasil pengamatan peneliti di Puskesmas Jagir, angka kejadian DM dengan ulkus diabetikum di Keluharan Bendul Merisi sebanyak 18 orang.

Upaya yang dapat dilakukan untuk mencegah agar kejadian komplikasi tidak bertambah parah dan tidak berdampak pada psikologis serta koping individu maladaptif adalah mengikutsertakan pasien dalam mengelola penataklaksanaan dirinya sendiri. Peran perawat juga sangat dibutuhkan agar dapat meningkatkan kemampuan pasien. Usaha yang dapat dilakukan oleh perawat antara lain dengan meningkatkan pengetahuan pasien tentang penyakitnya melalui penyuluhan kesehatan, pendidikan kesehatan, menjadi konselor untuk memotivasi dan mendukung pasien, serta melakukan kolaborasi dengan tim medis lain untuk proses pengobatan dan pengaturan diet pasien DM dengan ulkus diabetikum. Dalam hal ini, peneliti tertarik untuk mengidentifikasi kemampuan pasien dalam mengelola sakit penyakitnya dengan melakukan self management diabetes (SMD).

\section{METODE PENELITIAN}

Desain penelitian yang digunakan adalah deskriptif analitik, dimana tujuan utamanya adalah membuat gambaran tentang SMD pasien DM secara obyektif. Populasi dalam penelitian ini sejumlah 50 pasien DM dengan sampel sebanyak 18 responden menggunakan consecutive sampling. Waktu penelitian dilakukan pada tanggal 18-25 Mei 2020 di Puskesmas Jagir. Data dikumpulkan menggunakan kuisioner. Sebelum pengambilan data, terlebih dahulu peneliti meminta informed concent kepada responden, dan pada setiap lembar kuisioner yang terisi diberi kode.

\section{HASIL PENELITIAN DAN PEMBAHASAN}

\section{Hasil Penelitian}

Data umum berikut dibawah ini menggambarkan distribusi responden berdasarkan usia, jenis kelamin, lama menderita diabetes, pekerjaan, jarak dengan fasilitas kesehatan dan tinggal dengan keluarga.

Tabel 1 Distribusi responden berdasarkan usia di wilayah kerja Puskesmas Jagir Surabaya Mei 2020

\begin{tabular}{cccc}
\hline No & Usia (thn) & Frekuensi & Presentase \\
\hline 1. & $35-44$ & 4 & $22 \%$ \\
2. & $45-54$ & 3 & $17 \%$ \\
3. & $55-64$ & 7 & $39 \%$ \\
4. & $65-74$ & 1 & $5 \%$ \\
5. & $75-84$ & 3 & $17 \%$ \\
\hline & Total & 18 & $100 \%$ \\
\hline
\end{tabular}

Berdasarkan tabel 1 di atas, responden terbanyak berusia 55-64 tahun yaitu terbanyak 7 orang (39\%).

Tabel 2 Distribusi responden berdasarkan jenis kelamin di wilayah kerja Puskesmas Jagir Surabaya Mei 2020 


\begin{tabular}{cccc}
\hline No & Jenis Kelamin & Frekuensi & Presentase \\
\hline 1. & Laki-Laki & 12 & $67 \%$ \\
2. & Perempuan & 6 & $33 \%$ \\
\hline & Total & 18 & $100 \%$ \\
\hline
\end{tabular}

Berdasarkan tabel 2 di atas, sebagian besar responden adalah laki-laki yaitu 12 orang $(67 \%)$.

Tabel 3 Distribusi responden berdasarkan lama menderita diabetes di wilayah kerja Puskesmas Jagir Surabaya Mei 2020

\begin{tabular}{cccc}
\hline No & $\begin{array}{c}\text { Lama } \\
\text { Menderita } \\
\text { Diabetes }\end{array}$ & Frekuensi & Presentase \\
\hline 1. & 1-2 Tahun & 9 & $50 \%$ \\
2. & $3-4$ Tahun & 4 & $22 \%$ \\
3. & 5-6 Tahun & 5 & $28 \%$ \\
\hline & Total & 18 & $100 \%$ \\
\hline
\end{tabular}

Berdasarkan tabel 3 di atas, sebagian responden lama menderita diabetes melitus antara 1-2 tahun yaitu 9 orang (50\%).

Tabel 4 Distribusi responden berdasarkan pekerjaan di wilayah kerja Puskesmas Jagir Surabaya Mei 2020

\begin{tabular}{lccc}
\hline No & Pekerjaan & Frekuensi & Presentase \\
\hline 1. & Ibu rumah tangga & 2 & $11 \%$ \\
2. & Wiraswasta & 7 & $39 \%$ \\
3. & Guru & 1 & $6 \%$ \\
4. & Pensiunan & 6 & $33 \%$ \\
5. & Wirausaha & 2 & $11 \%$ \\
\hline & Total & 18 & $100 \%$ \\
\hline
\end{tabular}

Berdasarkan tabel 4 di atas, responden terbanyak bekerja wiraswasta yaitu 7 orang (39\%).

Tabel 5 Distribusi responden berdasarkan jarak dengan fasilitas kesehatan di wilayah Puskesmas Jagir Surabaya Mei 2020

\begin{tabular}{lccc}
\hline No & $\begin{array}{c}\text { Jarak Dengan } \\
\text { Fasilitas } \\
\text { Kesehatan (Km) }\end{array}$ & Frekuensi & Presentase \\
\hline 1. & $<1$ & 7 & $39 \%$ \\
2. & $1-2$ & 9 & $50 \%$ \\
3. & $3-4$ & 2 & $11 \%$ \\
\hline & Total & 18 & $100 \%$ \\
\hline
\end{tabular}

Berdasarkan tabel 5 diatas jarak dengan fasilitas kesehatan yang ditempuh responden terbanyak yaitu 1-2 Km sejumlah 9 orang $(50 \%)$.
Tabel 6 Distribusi responden berdasarkan tinggal dengan keluarga di wilayah kerja Puskesmas Jagir Surabaya Mei 2020

\begin{tabular}{cccc}
\hline No & $\begin{array}{c}\text { Tinggal Dengan } \\
\text { Keluarga }\end{array}$ & Frekuensi & Presentase \\
\hline 1. & Ya & 18 & $100 \%$ \\
2. & Tidak & 0 & 0 \\
\hline & Total & 18 & $100 \%$ \\
\hline
\end{tabular}

Berdasarkan tabel 6 di atas, seluruh responden tinggal dengan keluarga yaitu 18 orang $(100 \%)$.

Distribusi data mengenai self management diabetes pada pasien diabetes melitus dengan ulkus diabetikum

Tabel 7 Distribusi self management diabetes pada pasien diabetes dengan ulkus diabetikum di Puskesmas Jagir Surabaya Mei 2020

\begin{tabular}{cccc}
\hline No & $\begin{array}{c}\text { Self } \\
\text { Management } \\
\text { Diabetes }\end{array}$ & Frekuensi & Presentase \\
\hline 1. & Baik & 8 & $44 \%$ \\
2. & Cukup & 10 & $56 \%$ \\
3. & Kurang & 0 & 0 \\
\hline & Total & 18 & $100 \%$ \\
\hline
\end{tabular}

Berdasarkan tabel 7 di atas sebagian besar responden memiliki self management diabetes dengan katagori cukup sebanyak 10 orang $(56 \%)$.

\section{Pembahasan}

Pada pembahasan ini akan difokuskan pada hasil pengukuran SMD pasien diabetes melitus dengan ulkus diabetikum di Puskemas Jagir Surabaya".

Tabel 8 menunjukkan bahwa sebagian besar responden memiliki self management diabetes yang cukup sebanyak 10 orang (56\%). Menurut Mulyani (2016), Self Management Diabetes merupakan tindakan seseorang dalam mengelola diabetes terutama dalam pengobatan dan untuk mencegah komplikasi dalam kurun waktu 8 minggu. Pendapat tersebut sejalan dengan Xu Pan \& Liu (2010), yang mengatakan Self Management Diabetes merupakan seperangkat perilaku yang dilakukan oleh individu dengan diabetes untuk mengelola kondisi mereka, termasuk minum 
obat, mengatur diet, melakukan aktivitas fisik, pemantauan glukosa darah mandiri, dan mempertahankan perawatan kaki yang baik.

Faktor-faktor yang dapat mempengaruhi keberhasilan penatalaksanaan self management diabetes diantaranya umur, tingkat pendidikan, pekerjaaan, jenis kelamin, strategi koping, efikasi diri, lamanya menderita diabetes, dukungan sosial, dukungan keluarga, asuransi, komunikasi antara pasien dan provider, bahasa dan budaya, kepercayaan terhadap efektivitas pengobatan (Hunt, 2012 ; Lou, 2015).

Berdasarkan tabel 1, responden yang menderita diabetes melitus adalah usia 35-44 tahun sebanyak 4 orang (22\%), 45-54 tahun sebanyak 3 orang (17\%), 55-64 sebanyak 7 orang (39\%), 65-74 tahun sebanyak 1 orang (5\%), dan 75-84 sebanyak 3 orang (17\%). Menurut penelitian Kusnanto (2019), pasien yang berusia tua cenderung mengalami penurunan fisik dan kognitif yang dapat mempengaruhi kemampuan dan keaktifannya untuk melakukan manajemen diri diabetes, selain itu timbulnya komplikasi pada usia tua juga akan mempengaruhi kemampuan pasien dalam melakukan perawatandiri. Namun penelitian Khasanah (2016), menyatakan bahwa klien yang lebih muda memiliki pemahaman yang cukup terkait dengan manajemen diri diabetes serta manfaat yang dirasakan jika melakukan aktivitas terkait pengelolaan DM dalam kehidupan sehari-hari, sedangkan mereka yang usianya lebih tua telah merasakan manfaat dari aktivitas perawatan diri diabetes yang telah dilakukan melalui pengalaman yang mereka sudah lakukan. Hasil penelitian Toobert (2013) menyimpulkan bahwa usia tidak mempengaruhi seseorang dalam melakukan manajemen diri atau perawatan diri diabetes. Berdasarkan hasil diatas dapat ditarik kesimpulan bahwa baik responden berusia dewasa awal hingga lansia, mereka seharusnya sama-sama merasa bertanggungjawab terhadap dirinya sendiri untuk memperhatikan manajemen pengelolaan diabetesnya, agar tercapainya kadar gula darah yang normal dan mencegah terjadinya komplikasi.

Penelitian ini menunjukkan bahwa sebagian besar responden berada di rentang usia 35-64 tahun, dimana dengan usia yang tergolong produktif ini individu diharapakan memiliki pemahaman yang baik terkait dengan perawatan diri berkaitan dengan komplikasi akibat penyakit diabetes melitus.

Berdasarkan tabel 3, menunjukkan bahwa lama menderita diabetes melitus responden, yaitu 1-2 tahun berjumlah 9 orang (50\%), 3-4 tahun 4 orang (22\%), 5-6 tahun 5 orang (28\%). Menurut Fatimah (2016) menyatakan bahwa terdapat hubungan yang signifikan antara lama menderita DM dengan manajemen diri diabetes $(\mathrm{p}$-value $=0,02)$ penelitian ini menyatakan lamanya sakit DM mengakibatkan seseorang memiliki manajemen diri kurang baik, dimana terjadi kerusakan sel dan fungsi dalam tubuh sehingga mudah timbul berbagai gangguan fisik dan metabolik. Penyakit DM yang berkepanjangan dapat memberikan efek psikologi, dimana pasien menunjukkan sikap negative dalam pengendalian diabetes melitus seperti sudah tidak ingin olahraga, merokok, dan kurangnya kepatuhan dalam pengobatan (Riley, Gerson \& Deninison, 2009). Penelitian lain yang dilakukan oleh Bertalina \& Purnama (2016), menyatakan bahwa faktor kejenuhan karena lamanya menderita DM dapat mempengaruhi kemampuan dan kemauan seseorang melakukan manajemen diri dalam menjalani perawatan pada pasien DM. Pada penelitian ini ditunjukan bahwa sebagian besar responden memiliki self menejemen cukup dengan lama menderita sebagian besar adalah antara 1 - 2 tahun. Hal ini dapat dikarenakan individu masih bersemangat dalam melakukan manajemen diri dan perawatan luka dengan harapan agar luka yang mereka alami dapat sembuh, untuk itu mereka berupaya agar bisa melakukan perawatan diri dengan baik dan mengikuti setiap arahan yang diberikan oleh tenaga kesehatan. 


\section{SIMPULAN DAN SARAN}

Self Management Diabetes pada penderita diabetes melitus dengan ulkus diabetikum sebagian besar termasuk dalam katagori cukup sebanyak 10 orang $(56 \%)$.

Dengan adanya penelitian ini, diharapkan Puskesmas dapat menjadi sarana dan memfasilitasi pelayanan kepada pasien khususnya pada pasien diabetes melitus dengan ulkus diabetikum melalui pemberian edukasi, promosi kesehatan terkait pengobatan dan penatalaksanaan DM agar pasien terhindar dari resiko komplikasi. Besar harapan peneliti kepada peneliti selanjutnya untuk melakukan mengkaji lebih dalam "Strategi meningkatkan dan mengoptimalkan Self Management Diabetes pada Pasien Diabetes dengan Ulkus Diabetikum".

\section{DAFTAR PUSTAKA}

Barbara, C. Long. 2002. Perawatan Medikal Bedah (Suatu Pendekatan Proses Keperawatan). Bandung : Yayasan Ikatatan Alumni Pendidikan Keperawatan Padjajaran.

Departemen Kesehatan RI. Pedoman Pengendalian Diabetes Melitus dan Penyakit Metabolik. Jakarta: Direktorat Pengendalian Penyakit Tidak Menular. 2010. Tersedia secara online di http://perpustakaan.depkes.go.id.8180/bi tstream/123456789/1/BK2008-

sep13.pdf. Diakses pada tanggal 8 April 2020

International Diabetes Federation (IDF). 2017. IDF Diabetes Atlas Eighth Edition.

Profil Puskesmas Jagir, 2017

Putri M. (2018). Hubungan tingkat pengetahuan dan self management diabetes pada tingkat stress menjalani diet penderita diabetes melitus, Surabaya.
Riskesdas. 2013. Riset Kesehatan Dasar (RISKESDAS) 2013. Jakarta: Badan Penelitian dan Pengembangan Kesehatan Kementerian Kesehatan RI.

Sugiarto, I. (2013). Faktor risiko yang berhubungan dengan terjadinya ulkus diabetik pada pasien diabetes mellitus tipe 2 di RSUD. Dr.Margono Soekarjo, Purwokerto. Universitas Jenderal Soedirman.

http://keperawatan.unsoed.ac.id/sites/def ault/files/SKRIPSI\%20SUGIARTO\%20 FID0090056 (Diakses 10 April 2020)

Soegondo. 2007. Penatalaksanaan Pasien Diabetes Mellitus. FKUI. Jakarta.

Susanti, Meilina. 2013. Dukungan Keluarga Meningkatkan Kepatuhan Diet Pasien Diabetes Mellitus Di Ruang Rawat Inap Rs. Baptis Kediri. Diperoleh dari:http://www.google.co.id/uri?sa=t\&r

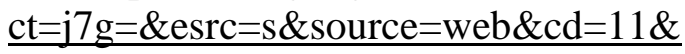
cad=rja\&auct $=8 \& v e d=0$ CBsQFjAAOA pqFQoTCPxqvijMcCFRNzjgod3ED0G \&url=http\%3A\%2F\%puslit2.petra.ac.id \%2fejaornal\%2Findex.php\%2Fstikes\%2 Farticel\%2Fview\%2F18840\%2F18537\& ei=4SaVb9L5PmuQTf44QDQ\&usg=AF QjCNHq3nuCEQY4p0FWFynmNWT4J 3Dyw\&bvm=bv.99261572,d.c2E(diakse s tanggal 28 April 2020)

World Health Organization WHO. (2013). Diabetes fakta dan angka

Yuni (2012). Tingkat pengetahuan pasien diabetes melitus tentang manajemen diabetes melitus di Rumah Sakit pusat Angkatan darat Gatot Soebroto, Jakarta Pusat 